\title{
THE OPEN INNOVATION PROCESS IN SPA \& WELLNESS TOURISM
}

\section{ELŻBIETA SZYMAŃSKA, ${ }^{1}$ ANDRZEJ RUTKOWSKI, ${ }^{2}$ EUGENIA PANFILUK ${ }^{3}$}

RECEIVED

ACCEPTED

JEL

CLASSIFICATION

KEYWORDS

ABSTRACT

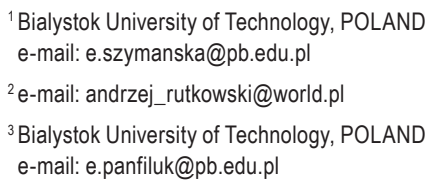

1 March 2016

1 June 2016

03, I1

innovation, tourism, spa \& wellness, theoretical model

The main purpose of this article is to create a theoretical model of the SPA \& wellness tourism innovation process. The research problem is innovation in SPA \& wellness tourism.

This article presents the results of an expert panel. The survey involved 12 experts, scientists and practitioners specializing in the fields of innovation and the economics of tourism, with particular emphasis placed on health tourism. The results of pilot studies carried out in April 2015 showed that innovative processes related to SPA $\&$ wellness were open.

The direct result of the research involves the model of the innovation process in SPA \& wellness tourism. The expected results will have an effect on the development of economic sciences. The project is novel in character, since to date the innovations occurring in SPA \& wellness tourism have not been classified and there is no model of its innovativeness.

\section{Introduction}

Innovation is perceived as the major driver of economic growth (Samuelson, Nordhaus, 2012). Therefore, the innovation issues have been discussed in many publications. The most important publications include those by J.A. Schumpeter, considered to be the father of innovation theory (1932). Contemporary economic studies, including primarily the Oslo Manuals (2005) indicate that innovation can be found not only in manufacturing enterprises but 
also in services. However, there have been few studies on innovation in services (OECD, 2005; Gault, 2015), particularly in tourism services (Hjalager, 2002; OECD, 2006; Szymańska, 2009; Szymańska, 2013). The research problem is innovation in SPA \& wellness tourism. Since SPA \& wellness tourism develops dynamically, there are more and more publications on this subject matter on the publishing market. They are mainly descriptive and reporting in character. The main purpose of the paper is to create a theoretical model of the SPA \& wellness tourism innovation process. This article presents the results of the expert panel. The survey was conducted in two rounds, from April to July 2015, using the Delphi method. The project is novel in character, since to date the innovations occurring in SPA \& wellness tourism have not been classified and there is no model of its innovativeness.

\section{The literature review}

The term "innovation" comes from Latin and means "renewal" (Kopaliński, 1978). H. Chesbrough (2003) was the precursor of the concept of open innovation. Computerisation and the networking of society and the economy made it possible for the intellectual resources which are external to a company to be incorporated into the process of creating innovation. It opens up to different partners (companies, organisations, customers), treating them as innovators. On the basis of this idea, many publications have appeared and there has also been an attempt to implement it in some countries of the European Union, since its assumptions perfectly fit the idea of a united, democratic Europe (Bos, te Velde, Gillebaard, 2010). Open innovation has become a new, networked source of a competitive edge (Łobejko, 2010).

SPA tourism is a form of health tourism based on the use of mineral water for health purposes. The term "SPA" is an acronym from the Latin phrase sanus per aquam, meaning "healthy through water". Remains of SPA sites can be found in the land which used to be ruled by the Roman empire. The wellness philosophy was created by Dr. Halbert Dunn, an American physician in 1959. In his theory, for the first time he combined two notions: fitness and well-being (well + fitness). According to him Bushell and Sheldon (2009), defined wellness tourism as a holistic mode of travel that integrates a quest for physical health, beauty or longevity. Health tourism, including wellness \& SPA was the subject of research in some Polish publications (Koźmiński et al., 2013). The development encourages investment in a region, enhances employment and improves the attractiveness of the region, contributing to improved health and satisfaction with one's life (Sheldon, Park, 2008).

\section{Methods}

Delphi is a qualitative method combining experts' knowledge and opinions to reach a conscious consensus on a complex problem, which is understood to mean a structured process of group communication designed to ensure the effectiveness of actions taken by a community of independent persons who are all committed to solving a complex problem (Linstone, Turoff, 2002). The panel consisted of 12 experts who offered knowledge in the scope of: the management of a tourism enterprise (entrepreneurs and scientific researchers in the field of tourism economics), geriatry, sustainable development, the international economy and nongovernmental organizations dealing with health tourism. The survey made it possible to verify and correct the survey questionnaire prepared using the CAVI method. The evaluation was made at the scale from 0 (insignificance) to 5 (key significance). In the survey proper, the respondents filled a questionnaire where they presented forecasts concerning a problem or situation in the field of innovation in health tourism, including SPA \& wellness. The experts were presented with 9 systems of innovation processes, based on Szymańska (2013, pp. 68-85), along with their brief characteristics, as 
follows: two linear models (pulled by the market and pushed by knowledge), conjugated, integrated and networked systems, information and communication technology systems, self-learning systems, user driven innovation, diffuse innovation systems and open innovation. In order for them to choose not more than two of them which would be most suitable for the specific forms of health tourism (health resort-based tourism, SPA \& wellness tourism, medical tourism and the tourism related to aesthetic medicine). They considered that the most suitable systems were open innovation and the innovation pulled by the market. There were taken by experts into research the business environment of service providers and their suppliers in the innovation process of SPA \& wellness tourism.

\section{The model of SPA \& wellness innovation}

It turned out that the model which combined two models occurring in innovation theory and could be called the open and pulled model was most appropriate for the innovation system of SPA \& wellness tourism. The attempt to design such a model is shown in Figure 1.



Figure 1. The innovation system model for SPA \& wellness tourism (open and pulled by the market)

Source: own elaboration based on the Delphi survey and $\mathrm{H}$. Chesbrough, Open innovation. The new imperative for creating and profiting from technology, Harvard Business School Press, Boston, 2003.

The elements characteristic of both models are shown here, i.e. the market element, the particularly important customers' roles in innovation processes and their being open to the external environment. H. Chesbrough (2003) showed this process in the form of a screen where new ideas originating in companies or in their environment enable the creation of innovations on the present market, but also enable the creation of new markets. Combined with a linear model pulled by the market, it makes it possible to place the innovation system of SPA \& wellness tourism on many markets and close to the customer.

\section{Results of research}

Detailed results of the Delphi survey led to important conclusions. First of all, the innovative processes present in this form of tourism were determined (Figure 1) and a list of entities involved in the provision of SPA \& wellness tourism services was also proposed (Table 1). 
Table 1. The entities involved in the provision of SPA \& wellness tourism services and their role in the innovation process, by experts $(\%)$

\begin{tabular}{|c|c|c|c|c|c|}
\hline Entities & Play no role & $\begin{array}{l}\text { Facilitate diffusion } \\
\text { of innovation }\end{array}$ & $\begin{array}{c}\text { Ensure } \\
\text { commercialisation } \\
\text { of innovation }\end{array}$ & $\begin{array}{c}\text { Create } \\
\text { the innovation core }\end{array}$ & $\begin{array}{c}\text { Participate } \\
\text { in creating the idea } \\
\text { of innovation }\end{array}$ \\
\hline Hospitals & 67 & 17 & 17 & 0 & 0 \\
\hline Outpatient clinics & 75 & 17 & 0 & 8 & 0 \\
\hline Long-term care centres & 67 & 25 & 8 & 0 & 0 \\
\hline Private centres & 0 & 17 & 25 & 25 & 33 \\
\hline Specialised physiotherapy centres & 0 & 25 & 8 & 25 & 42 \\
\hline Health resort-based treatment units & 0 & 25 & 33 & 25 & 17 \\
\hline $\begin{array}{l}\text { Medical services rendered by natural } \\
\text { persons, physiotherapists, speech } \\
\text { therapists }\end{array}$ & 0 & 17 & 33 & 8 & 42 \\
\hline Travel agencies & 42 & 42 & 8 & 8 & 0 \\
\hline Tour operators & 8 & 42 & 33 & 8 & 8 \\
\hline Tourism providers & 42 & 25 & 25 & 0 & 8 \\
\hline Hotels & 0 & 8 & 25 & 50 & 17 \\
\hline Other accommodation facilities & 25 & 17 & 25 & 25 & 8 \\
\hline
\end{tabular}

Source: own elaboration based on the Delphi survey.

The greatest importance in the innovation process was attributed to hotels which could be the innovation core ( $50 \%$ of indications). The entities which created innovations included primarily specialised physiotherapy centres and natural persons providing medical services ( $42 \%$ each), followed by private centres (33\%). Tour operators and travel agencies ensured the diffusion of innovation (44\% of indications on average each). Agencies also ensured the commercialisation of innovation, as indicated by the third best indication of the experts. The same number of indications was awarded to natural persons providing medical services and health resort-based treatment units. Subsequently, the respondents evaluated different organisations in terms of their effect on innovation in SPA \& wellness tourism (Table 2).

The results presented in the Table demonstrate that innovation in SPA \& wellness tourism is to a large extent affected by specialised Internet-based resources (50\% of indications). Some impact in the sectoral system is attributed to research institutes $(50 \%)$, followed by sectoral media (42\%) and organisations associating representatives of medical professions and cosmetologists (33\%). The evaluation of the business environment of service providers and their suppliers demonstrated that it was only financial institutions and research institutes (42\% each) that had some impact. The evaluation also covered relevant factors in respect of their impact on innovation in SPA \& wellness tourism (Table 3).

The business environment of service providers and their suppliers could play a significant role in this process. The highest - key - significance (42\%) of indications was attributed to a good reputation of medical personnel, followed by certification (33\%). An efficient control system and openness to international cooperation system also played a large role ( $42 \%$ of indications each). The legal regulations protecting customers, the willingness to cooperate and the culture of improving skills were important as well (33\% of indications each). The willingness to share information was important to a certain, though minor extent (50\%). 
Table 2. Organisations in the sectoral innovation system of SPA \& wellness tourism (\%)

\begin{tabular}{|c|c|c|c|c|c|c|}
\hline Organisations & 0 & 1 & 2 & 3 & 4 & 5 \\
\hline Higher education establishments & 16.67 & 25.00 & 25.00 & 25.00 & 8.33 & 0.00 \\
\hline Research institutes & 0.00 & 16.67 & 8.33 & 50.00 & 0.00 & 25.00 \\
\hline Consulting companies & 8.33 & 50.00 & 8.33 & 25.00 & 0.00 & 8.33 \\
\hline $\begin{array}{l}\text { Organisations associating representatives of medical } \\
\text { professions and cosmetologists }\end{array}$ & 0.00 & 16.67 & 25.00 & 33.33 & 16.67 & 8.33 \\
\hline $\begin{array}{l}\text { Sectoral organisations of suppliers of medical } \\
\text { and cosmetological agents and equipment }\end{array}$ & 0.00 & 0.00 & 58.33 & 25.00 & 0.00 & 16.67 \\
\hline Sectoral organisations of the tourism industry & 8.33 & 41.67 & 16.67 & 16.67 & 8.33 & 8.33 \\
\hline Sectoral media & 0.00 & 16.67 & 8.33 & 41.67 & 16.67 & 16.67 \\
\hline General media & 25.00 & 25.00 & 8.33 & 16.67 & 25.00 & 0 \\
\hline Training enterprises & 16.67 & 41.67 & 25.00 & 8.33 & 8.33 & 0 \\
\hline Specialised Internet-based resources & 0.00 & 16.67 & 16.67 & 16.67 & 50.00 & 0 \\
\hline Government administration & 41.67 & 33.33 & 8.33 & 16.67 & 0 & 0 \\
\hline Insurance companies & 41.67 & 25.00 & 25.00 & 8.33 & 0 & 0 \\
\hline
\end{tabular}

Source: own elaboration based on the Delphi survey.

Table 3. Institutions in the sectoral innovation system of health tourism (\%)

\begin{tabular}{|c|c|c|c|c|c|c|}
\hline Specification & 0 & 1 & 2 & 3 & 4 & 5 \\
\hline Certification systems & 0.00 & 16.67 & 8.33 & 25.00 & 16.67 & 33.33 \\
\hline Efficient control system & 25.00 & 8.33 & 16.67 & 8.33 & 41.67 & 0.00 \\
\hline Legal regulations protecting consumers & 8.33 & 25.00 & 8.33 & 25.00 & 33.33 & 0.00 \\
\hline Good reputation of medical personnel & 8.33 & 0.00 & 25.00 & 25.00 & 0.00 & 41.67 \\
\hline Willingness to share information & 0.00 & 8.33 & 50.00 & 16.67 & 25.00 & 0.00 \\
\hline Willingness to cooperate & 0.00 & 25.00 & 33.33 & 8.33 & 33.33 & 0.00 \\
\hline Culture of improving skills & 0.00 & 8.33 & 25.00 & 16.67 & 33.33 & 16.67 \\
\hline Openness to international cooperation & 8.33 & 8.33 & 8.33 & 8.33 & 41.67 & 25.00 \\
\hline Cooperation between public and private sectors & 25.00 & 33.33 & 8.33 & 8.33 & 16.67 & 8.33 \\
\hline
\end{tabular}

Source: own elaboration based on the Delphi survey.

Table 4. The institutions in the regional innovation system of SPA \& wellness tourism (\%)

\begin{tabular}{lrrrrrr}
\hline \multicolumn{1}{c}{ Specification } & \multicolumn{1}{c}{ } & 1 & 2 & 3 & 4 & 5 \\
\hline Openness to tourists & 0.00 & 0.00 & 8.33 & 16.67 & 25.00 & 50.00 \\
\hline Local medical traditions & 25.00 & 41.67 & 0.00 & 8.33 & 16.67 & 8.33 \\
\hline Willingness to cooperate between different entities & 8.33 & 16.67 & 41.67 & 0.00 & 25.00 & 8.33 \\
\hline Availability of information on local resources & 0.00 & 16.67 & 8.33 & 58.33 & 16.67 & 0.00 \\
\hline Openness to external investors & 16.67 & 0.00 & 0.00 & 41.67 & 25.00 & 16.67 \\
\hline Support of the public sector for investors & 16.67 & 16.67 & 16.67 & 16.67 & 16.67 & 16.67 \\
\hline International linkages & 0.00 & 16.67 & 8.33 & 8.33 & 41.67 & 25.00 \\
\hline Education level of local residents & 16.67 & 25.00 & 8.33 & 25.00 & 25.00 & 0.00 \\
\hline Cooperation between public and private sectors & 8.33 & 25.00 & 8.33 & 33.33 & 16.67 & 8.33 \\
\hline
\end{tabular}

Source: own elaboration based on the Delphi survey. 
The experts believed that the openness to tourists was of key importance for innovation in SPA \& wellness tourism ( $50 \%$ indications), that international linkages were also very important (42\% of indications) and that the availability of information on local resources (58\%), the openness to external investors (42\%) and the cooperation between public and private sectors (33\%) also played a certain role.

\section{The final model of SPA \& wellness innovation}

On the basis of the model designed (Figure 1) and taking into account the results shown in tables (Tables $1-4)$, the authors built the model presented below (Figure 2).



Figure 2. The innovativeness system model for SPA \& wellness tourism (open and pulled by the market)

Source: own elaboration based on the Delphi survey.

The model covered primarily the tourism market, in particular the tourist needs which occurred within the market (the first - grey - circle). A hotel can be the innovation core (the second - white - circle). Specialised physiotherapy centres and natural persons providing medical services participating in the creation of innovation were placed at the main axis of the innovation process. Tour operators and travel agencies ensuring the diffusion of innovation found themselves at the end of the "funnel". The entities ensuring the commercialisation of innovation: travel agencies, natural persons providing medical services and health resort-based treatment units were situated outside the innovation process (the last - grey - circle). Specialised Internet-based resources had a large impact on innovation in SPA \& wellness tourism; therefore, they were placed along the "funnel", on the border between the old and new markets. Another very important factors, i.e. a good reputation of medical personnel and certification, international linkages, were also taken into account. 


\section{Conclusions and recommendations}

The research performed was theoretical in nature. Its purpose was realised by creation the model of the innovation process in SPA \& wellness tourism. Some conclusions can be drawn on the basis of the research performed. Open innovation and the innovation pulled by the market are the most suitable systems for this innovation processes. The greatest importance was attributed to hotels, which could constitute the innovation core (50\%). Physiotherapy centres and natural persons providing medical services ( $42 \%$ each) participated in the creation of innovation. Tour operators and travel agents ensured to a large extent the diffusion of innovation (44\% of indications on average). Specialised Internet-based resources had a large impact on this process (50\% of indications). Among the institutions within the sectoral innovation system of SPA \& wellness tourism (the business environment of service providers and their suppliers), the key significance ( $42 \%$ of indications) was attributed to a good reputation of medical personnel. The openness to tourists was of key importance for innovation in SPA \& wellness tourism ( $50 \%$ of indications) and international linkages were also considered to be very important ( $42 \%$ of indications). One recommendation is that major independent variables should be taken into account when planning innovation in enterprises providing SPA \& wellness tourism services. However, it seems most important to respond to tourists' opinions and needs and to enter into cooperation with different entities, particularly at the international level.

\section{Acknowledgments}

The project has been financed with the resources of the National Science Centre granted on the basis of the decision No. DEC-2013/11/B/HS4/02138.

\section{References}

Aundretsch, D.B. (2004). Sustaining Innovation and Growth: Public Policy Support for Entrepreneurship, Industry and Innovation, 11.

Bos, J., te Velde, R. \& Gillebaard, H. (2010). United we stand: Open service innovation policy schemes; An international policy scan and two case studies - London and Helsinki metropolitan areas. Dialogic innovative interactive, Utrecht 8 October.

Bushell, R. \& Sheldon, P.J. (eds.) (2009). Wellness and Tourism: Mind, Body, Spirit, Place. New York: Cognizant Communication Corporation.

Chesbrough, H. (2003). Open innovation. The New imperative for creating and profiting from technology. Boston: Harvard Business School Press.

European Institute of Innovation and Technology (EIT) (2008). European Communities, Luxembourg.

Gault, F. (2015). Measuring innovation in all sectors of the economy. UNU-MERIT Working Paper.

Hjalager, A.-M. (2002). Repairing Innovation Defectiveness in Tourism. Tourism Management, 23.

Innovation and Growth in Tourism (2006). Paris: OECD.

Kopaliński, W. (1978). Słownik wyrazów obcych i obcojęzycznych. Warszawa: WP.

Koźmiński, C., Michalska, B., Szczepanowska, E. \& Górnik K. (2013). Zarys turystyki zdrowotnej i uzdrowiskowej. Szczecin: Wydawnictwo Naukowe Uniwersytetu Szczecińskiego.

Linstone, H.A. \& Turoff, M. (2002). Introduction. In: H.A. Linstone, M. Turoff (ed.), The Delphi Method. Techniques and Applications. Murray Turoff and Harold A. Linstone.

Łobejko, S. (2010). Przedsiębiorstwo sieciowe. Zmiany uwarunkowań i strategii w XXI wieku. Warszawa: Szkoła Główna Handlowa w Warszawie.

Plummer, R. \& Armitage, D.R. (2007). Charting the New Territory of Adaptive Co-management: A Delphi Study. Ecology and Society, $12(2)$.

Schumpeter, J.A. (1932). The Theory of Economic Development. Harvard Economic Studies. 
Service Research and Innovation Institute. Available at: www.thesrii.org (30.08.2014).

Sheldon, P.J. \& Park, S.Y. (2008). Sustainable Wellness Tourism: Governance and Entrepreneurship Issue. Acta Turistica, 20 (2), $151-172$.

Szymańska, E. (2009). Innowacyjność przedsiębiorstw turystycznych w Polsce. Białystok: Oficyna Wydawnicza Politechniki Białostockiej.

Szymańska, E., (2013). Procesy innowacyjne przedsiębiorstw świadczących usługi w zakresie organizacji imprez turystycznych. Białystok: Oficyna Wydawnicza Politechniki Białostockiej.

UNWTO Tourism Highlights 2011 Edition (2011). UNWTO.

Voigt, C. \& Pforr, C. (eds.) (2014). Wellness Tourism: A Destination Perspective. London: Routledge.

Walder, B., Weiermair, K. \& Perez A.S. (eds.) (2006). Innovation and Product Development in Tourism. Berlin: Erich Schmidt Verlag.

Cite this article aS: Szymańska, E., Rutkowski, A., Panfiluk, E. (2016). The open innovation process in SPA \& wellness tourism. European Journal of Service Management, 19 (3), 59-66. DOI: 10.18276/ejsm.2016.19-08. 